\title{
Pulmonary Valve Insufficiency as a Complication of Radical Surgical Treatment of Tetralogy of Fallot
}

\author{
Milovan Stojanović ${ }^{1}$, Marina Deljanin-Ilićc ${ }^{1,2}$, Aleksa Vuković ${ }^{1}$, Dejan Petrović ${ }^{1,2}$ \\ ${ }^{1}$ Institute for Treatment and Rehabilitation, Niška Banja, Niš, Serbia \\ ${ }^{2} U$ niversity of Niš, Faculty of Medicine, Niš, Serbia
}

\begin{abstract}
SUMMARY
Tetralogy of Fallot is the most common cyanogenic congenital heart defect. The diagnosis is based on clinical signs, ECG examination, ultrasound examination of the heart, additional imaging methods and invasive testing. The therapeutic approach to the patient with tetralogy is complex and based on conservative and radical methods. Patients who have not undergone a radical surgical intervention have a poor prognosis, whereas the prognosis is much better for patients who have been operated. The most common complication of the surgical treatment is the pulmonary valve insufficiency which usually requires reintervention, as was the case with our patient.
\end{abstract}

Key words: tetralogy of Fallot, congenital heart defects, pulmonary valve insufficiency

Corresponding author:

Milovan Stojanović

Email: milovanstojanovic1987@gmail.com 


\section{INTRODUCTION}

The tetralogy of Fallot is the most common cyanogenic congenital heart defect (1). It was named after Arthur Fallot, the French scientist who described the defect in 1888 (2), characterized by the presence of ventricular septal defect (VSD), dextroposition of the aorta, obstruction of the right ventricular outflow tract and right ventricular hypertrophy (3). If, accompanied with these characteristics, there is an atrial septal defect, then we have the case of pentalogy of Fallot (4). The etiology of this tetralogy is still unknown, but it is assumed that prenatal factors and genetics play a very important role in the occurrence of this heart defect (5-7). Although being the most common cyanogenic heart defect, the tetralogy accounts for only $10 \%$ of all congenital heart defects (8).

The clinical presentation of tetralogy is usually associated with "blue baby syndrome". While playing, crying or eating, a child suddenly turns blue, looses consciousness and stops breathing (9). Unless the reaction is prompt and adequate, the outcome may be lethal. In older children with tetralogy, a delayed psychomotor development can occur, as well as blood hyperviscosity, the phenomenon of hairy fingers and paradoxical embolism (10). Also, it has been found that the quality of life of non-operated patients is much worse than in operated patients (11). The clinical picture depends on the severity of the obstruction of the right ventricular outflow tract, followed by the size of a VSD.

\section{CASE REPORT}

A male patient, NN, born in 1980 in Novi Pazar, came for the treatment and rehabilitation after the surgical treatment of tetralogy of Fallot, tricuspid annuloplasty and pulmonary valve replacement by a biological heart valve. The medical documentation revealed that the patient was diagnosed with a congenital heart defect - tetralogy of Fallot, after a routine examination in the second month of his life. In the same year, in the seventh month of his life, the patient underwent a mild surgical intervention of the right lung and right subclavian artery anostomosis, when the BlalockTausigg method was performed. In the third year of his life, a radical surgical intervention was performed.

In 1989 the patient underwent the second cardiac catheterization which verified the existence of pulmonary valve insufficiency, but the idea of the valve replacement was abandoned because of the high operational risk. In 1997, after the third consecutive catheter- rization, stenosing lesions on the right and left pulmonary artery were verified.

The patient subjectively felt well until 2013 when he was hospitalized with the signs of right heart failure and newly found atrial fibrillation which was converted to sinus rhythm after applying medicaments. The ultrasound examination registered a significant insufficiency of the pulmonary and tricuspid valve.

In January 2016, while walking up the stairs, the patient felt a sudden acceleration of the heartbeat, which was followed by a loss of consciousness. The ECG registered a new episode of atrial fibrillation. Because of these problems, the patient was hospitalized in a reference institution for radio frequency ablation of atrial fibrillation. The procedure could not be performed because of a left atrial thrombus observed at the transesophageal ultrasound examination of the heart. Finally, in March 2016, a radical surgical intervention was performed - a resection of the right ventricular outflow tract and right ventricular remodeling, as well as tricuspid valve annuloplasty with Countur ring, replacement of the pulmonary valve by the biological valve Hancock No27 and surgical ablation of absolute arrhythmia.

After surgery, the patient was indicated for cardiovascular rehabilitation in the Institute "Niška Banja". On admission to the Institute, the patient did not have pain in the chest or suffocation (Figure 1).

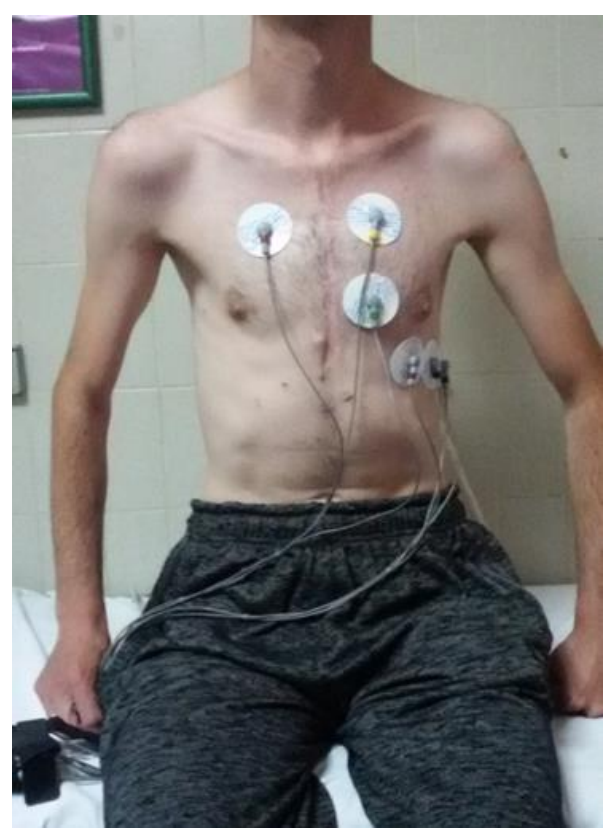

Figure 1. Patient's marfanoid appearance 
There were no obstructions or delays in the lungs. The heart action was rhythmic, the tones clear, and there was a systolic murmur over the pulmonary artery and systolic-diastolic murmur over the Erb.

There was no swelling on the lower legs.
The ECG registered a sinus rhythm, a sign of total right bundle branch block. The duration of the QRS complex was around $210 \mathrm{msec}$ (Figure 2).

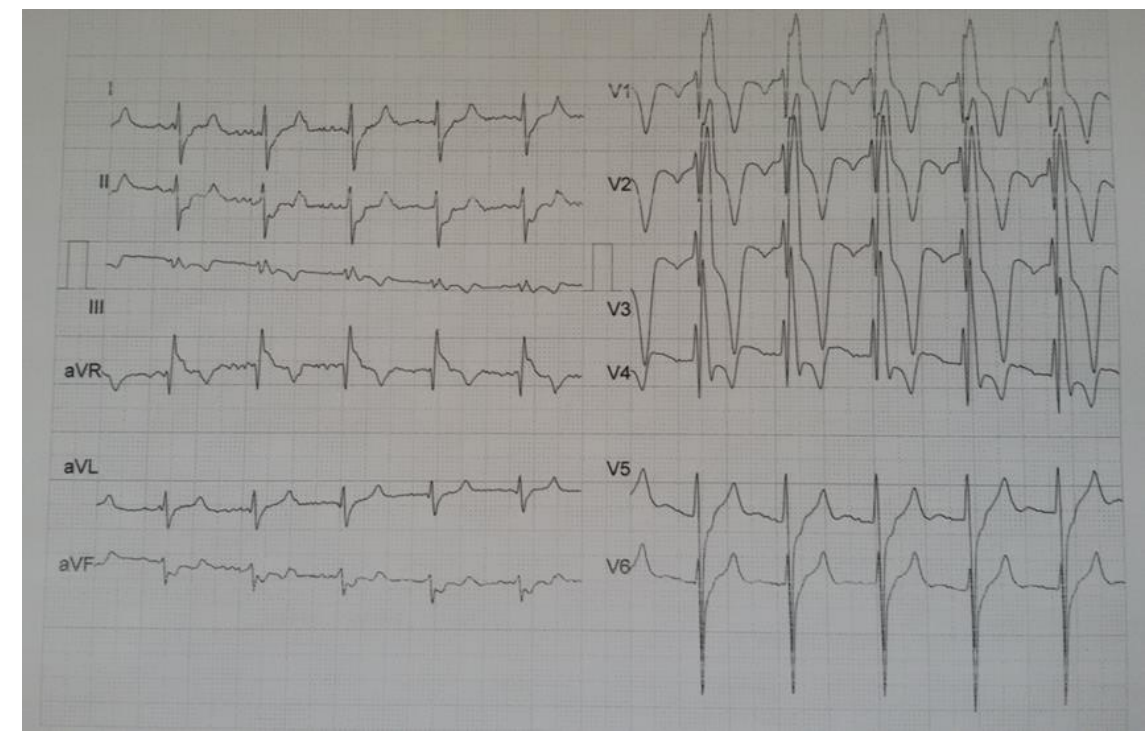

Figure 2. Electrocardiogram on admission to rehabilatation at the Institute

The radiographs of the heart and lungs showed that all four ports on the left cardiac contour were enlarged with an increase in Gradel-Marin index (Figure 3). The ultrasound examination of the heart showed preserved contractile power of the left ventricle,
EF $65 \%$, with no segmental turns in contractility. The gradient over the biological valve was $52 / 30 \mathrm{mmHg}$ (Figures 4 and 5).

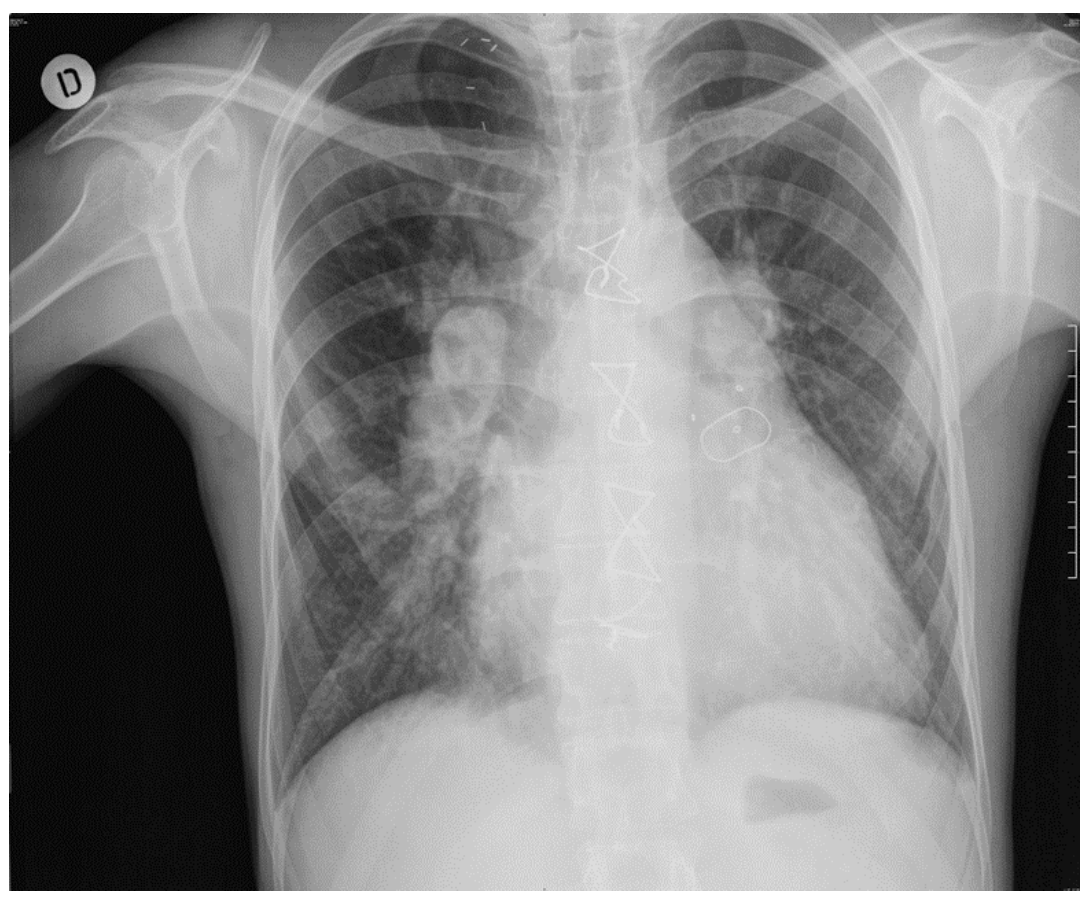

Figure 3. Radiographs of the heart and lungs 


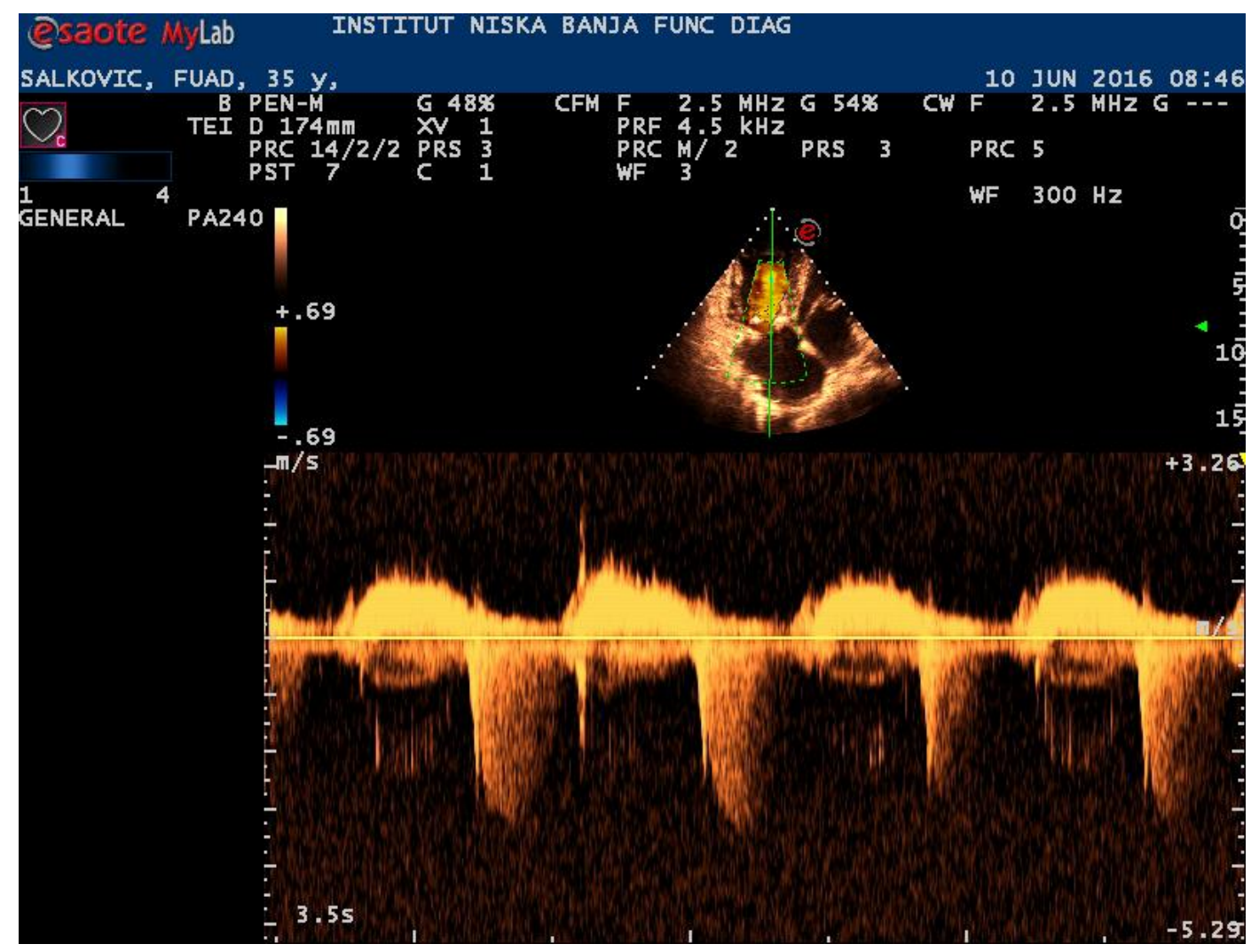

Figure 4. The ultrasound of the heart (1)

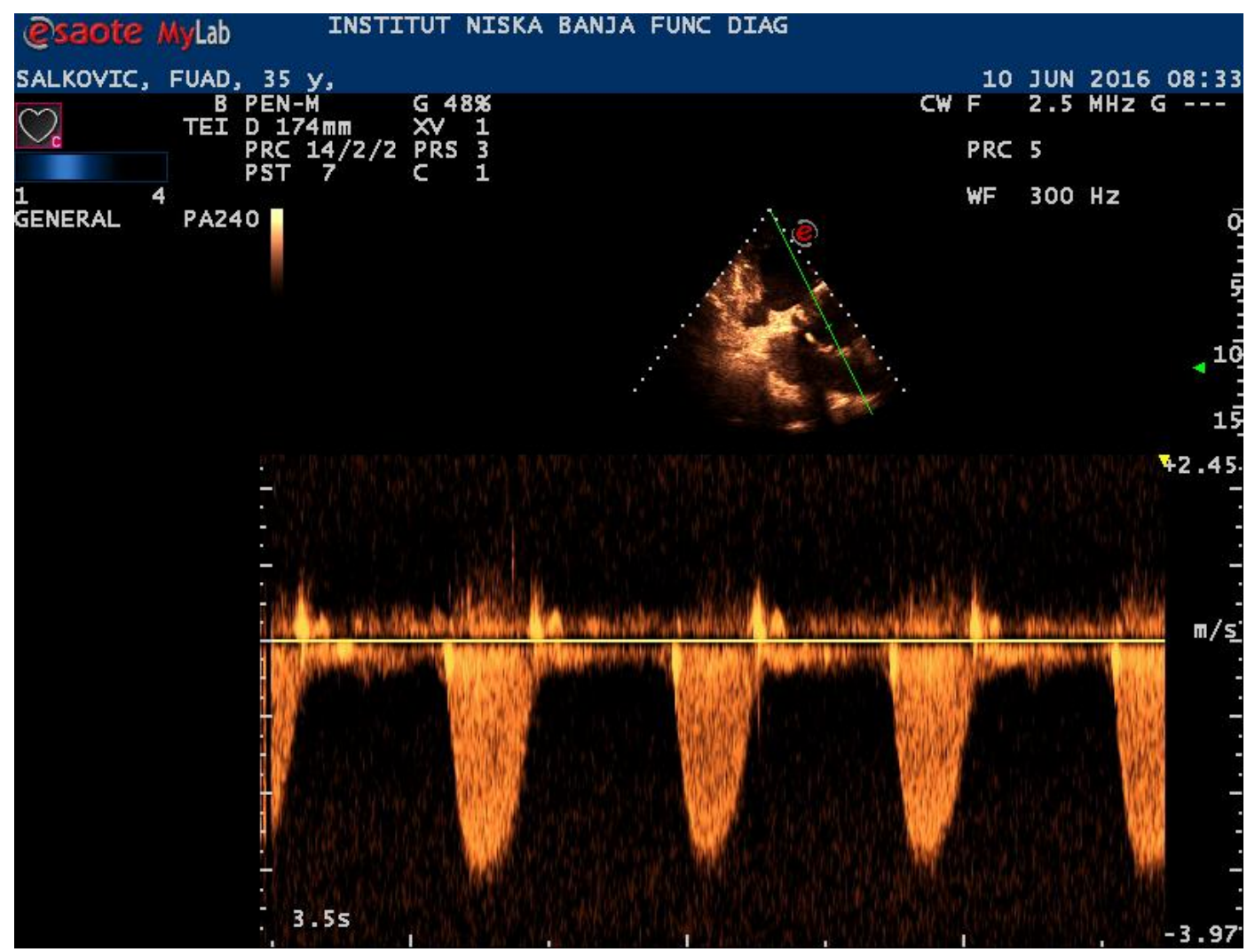

Figure 5. The ultrasound of the heart (2) 


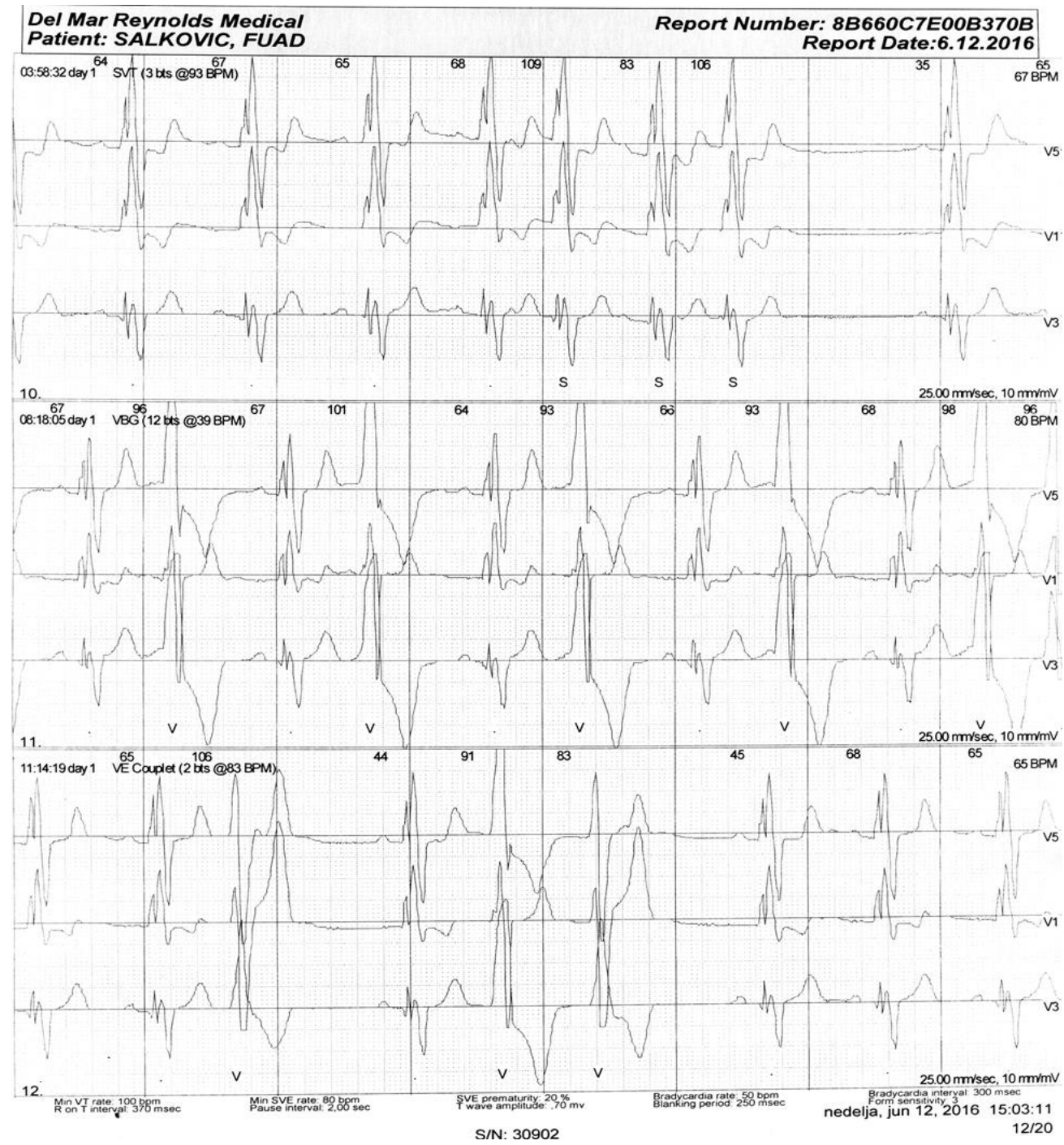

Figure 6. Holter ECG with frequent VES

The 24 Hour Holter ECG monitoring showed mainly a sinus rhythm without episodes of atrial fibrillation. The following results were recorded: 8548 monomorphic VES, out of which 9 episodes of VES trigeminy, 468 episodes of VES bigeminy and 146 VES pairs. Twenty-eight pauses in the cardiac work were registered - 20 post-extrasystolic pauses and 8 included in the SA block of II degree (Figures 6 and 7).

The ergospirometry test recorded poor cardiopulmonary fitness with decreased VO2 at VAT for sex and age (Figure 8 ).

During the patient's stay at the Institute, a program of cardiovascular rehabilitation was implemented (walkway, exercises, training on a bicycle ergometer, education) within a period of 21 days, with favorable therapeutic effect. During his stay at the Institute, the patient did not have chest pain or suffocation, he was hemodynamically stable and cardiologically compensa- ted. He was discharged in a stable general condition. The therapy on discharge: Tbl Farin according to INR, the prevention of infectious endocarditis.

\section{DISCUSSION}

The diagnosis of tetralogy of Fallot is based on the clinical picture, ECG examination, ultrasound examination of the heart, additional imaging methods and invasive testing. The patients with tetralogy of Fallot registered on ECG are expected to show signs of the right ventricular hypertrophy with systolic load or signs of total right bundle branch block, while in operated patients the total right bundle branch block is the most common finding (12-14). Ultrasound examination of the heart remains the gold standard for diagnosing congenital heart defects $(15,16)$. 


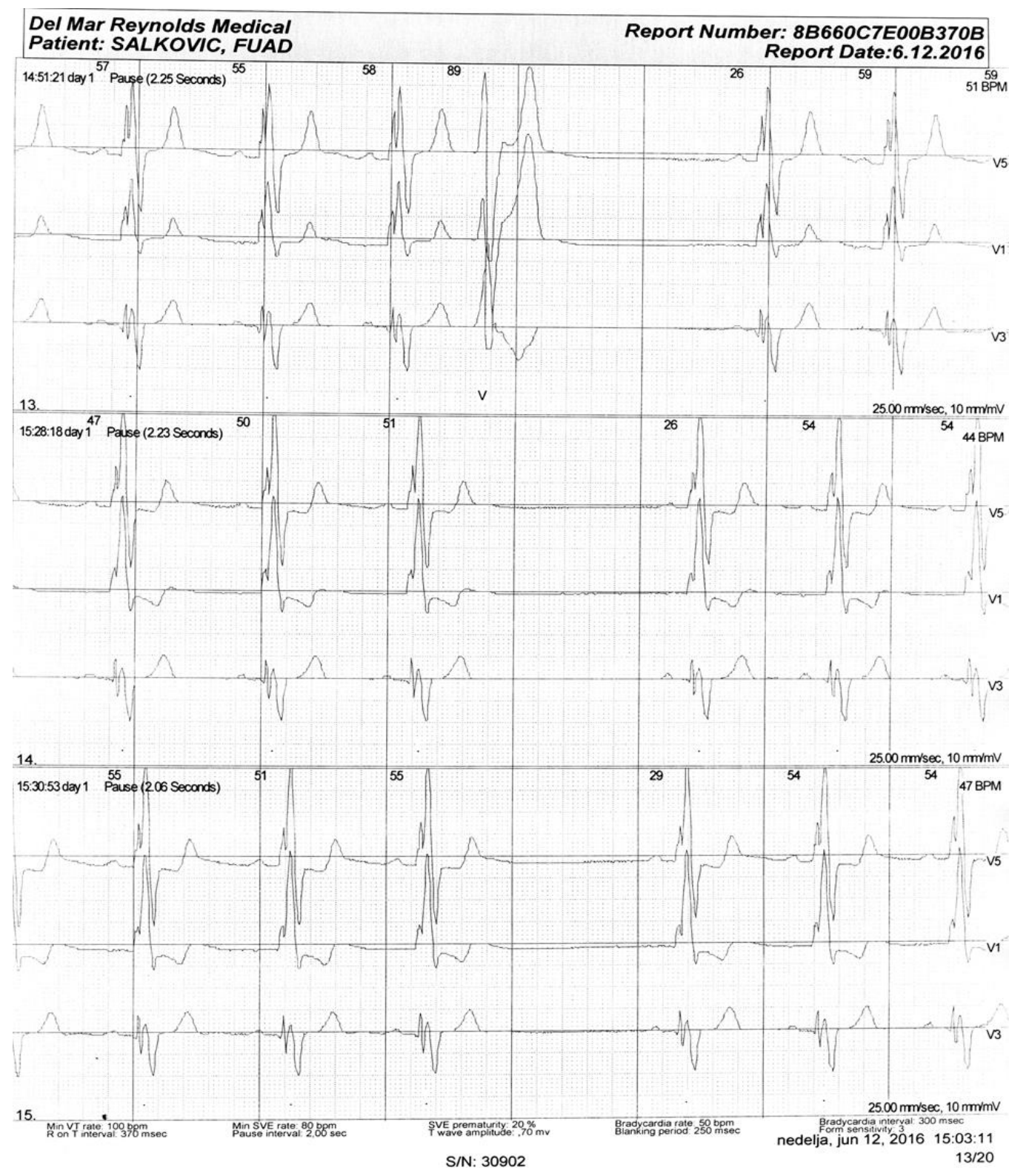

Figure 7. Holter ECG with frequent pauses

The therapeutic approach to the patients with tetralogy is complex and based on both conservative and radical methods. Children often take a crouching position, which increases the peripheral vascular resistance, increases the pressure in the systemic circulation and thus reduces the weight of the right-to-left shunt. The pharmacological approach is based on administering prostaglandin E and / or Propranolol.

Prostaglandin prevents closure of the ductus arteriosus and thus increases the flow of blood through the lungs (17), whereas Propranolol due to its negative inotropic effect reduces the pressure in the right heart and due to its partial sympathomimetic activity increases pressure in the systemic circulation (18,
19). Surgical methods include a range of interventions, both mild and radical. The most common mild surgical intervention is the Blalock-Taussig method where anastomosis is created between the subclavian and pulmonary artery $(20,21)$. In recent years, the increasingly frequent method is stent-implanting in the right ventricular outflow tract (22). On the other hand, radical interventions include a myomectomy of the right ventricular outflow tract, right ventricular remodeling, closure of VSD and closure of the access to the truncus brahicephalicus. Parts of the patient's pericardium are used for the closure.The patient's prognosis depends on the thera-peutic approach. Patients who did not undergo the radical intervention have a poor prognosis (23). 


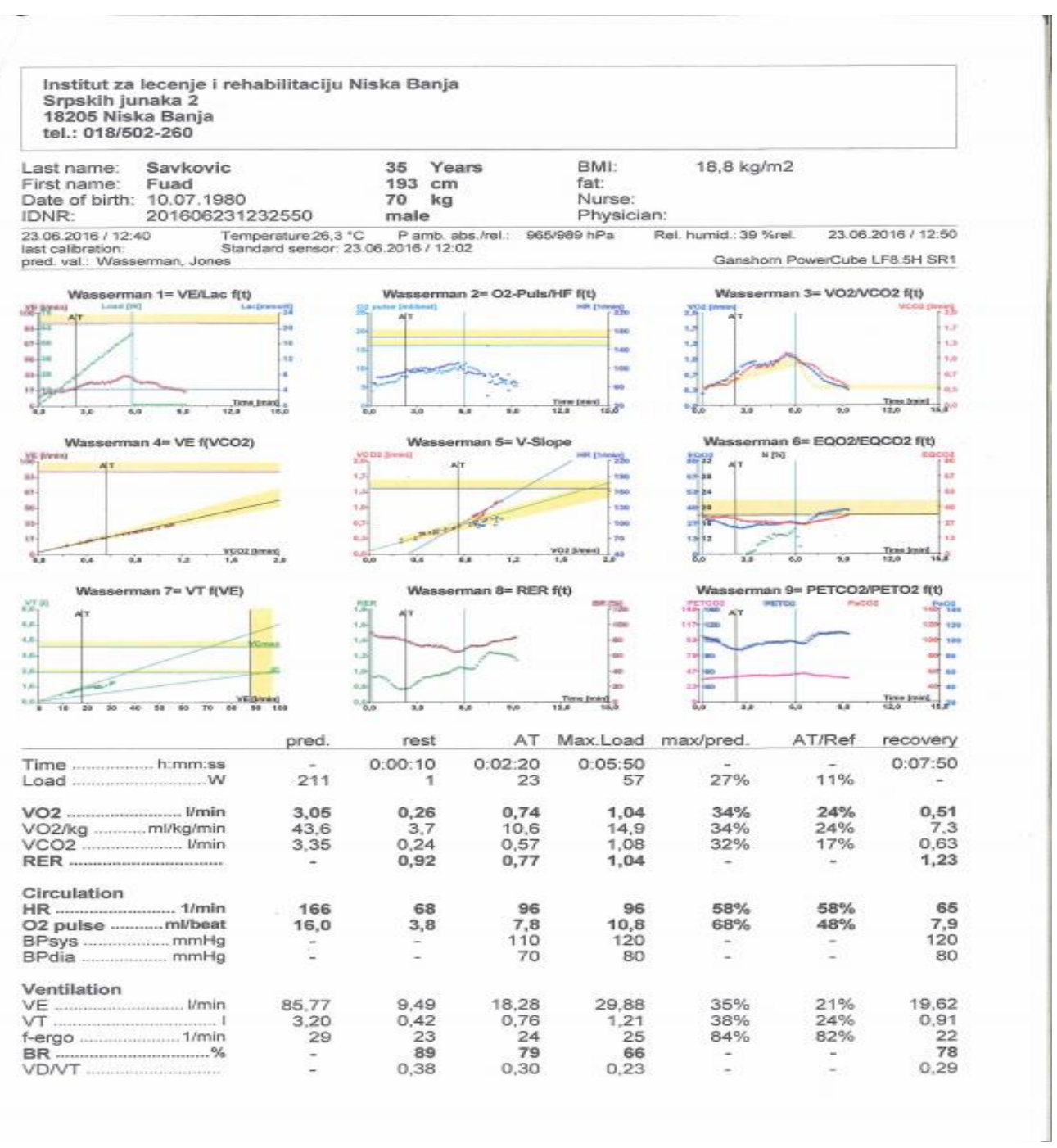

Figure 8. Ergospirometry test

The prognosis of the operated patients is much better $(24,25)$. The most difficult and the most common complication of the radical surgical approach is the pulmonary valve insufficiency. Therefore, the mild surgery becomes increasingly suggested, because it should preserve the pulmonary valve at the cost of partial myomectomy. Poor prognostic marker in our patient is the existence of a very high QRS complex because each increase above the value of $180 \mathrm{msec}$ proportionally carries a higher risk of sudden cardiac death (26). Besides, the major problems are complex disorders of the heart rhythm as the antiarrhythmic treatment has not given the expected results, so the possibility of implantation of cardioverter defibrillators in such patients should be taken into consideration (27).

\section{CONCLUSION}

A radical surgical approach remains the main and the best method for the treatment of tetralogy of Fallot. Just like other surgical procedures, the operation of this congenital heart defect also carries a risk of complications; however, the mortality rate during the surgery is very low. The most common complication is pulmonary valve insufficiency, which usually requires repeated intervention, as is the case with our patient. Our patient was treated with almost all conservative and surgical methods of treatment from palliative to radical ones, including the final pulmonary valve replacement and rehabilitation. 


\section{References}

1. Apitz C, Webb GD, Redington AN. Tetralogy of Fallot. Lancet 2009; 374 (9699):1462-71. https://doi.org/10.1016/S0140-6736(09)60657-7

2. Evans NW. Tetralogy of Fallot and Etienne-Louis Arthur Fallot. Pedriatic Cardiol 2008;29(3):637-40.

3. Bailliard F, Anderson HR. Tetralogy of Fallot. Orphanet J Rare Dis 2009;4:2. https://doi.org/10.1186/1750-1172-4-2

4. Mhaske S, Kotahri S, Machale G, et al. Pentalogy of Fallot. Indian JAnatomy 2014; 3(2):127-30.

5. Greenway SC, Pereira AC, Lin JC, et al. De novo copy number variants indentify new genes andloci in isolated sporadic tetralogy of Fallot. Nature Genetics 2009;41:931-35. https://doi.org/10.1038/ng.415

6. Nemer G, Fadlalah F, Usta J, et al. A novel mutation in the GATA4 gene in patients with Tatralogy of Fallot. Human Mutation 2006;27(3):293-4. https://doi.org/10.1002/humu.9410

7. Eldah ZA, Hamosh A, Biery NJ, et al.Familial Tetralogy of Fallot caused by mutation in the jagged1 gene. Human Molecular Genetics 2016;10(2):163-69. https://doi.org/10.1093/hmg/10.2.163

8. Pinsky WW, Arciniegas E. Tetralogy of Fallot. Pediatric Clinics of North America 1990; 37(1):179 92. https://doi.org/10.1016/S0031-3955(16)36839-0

9. Starr JP. Tetralogy of Fallot: Yesterday and today. World J Surg 2010;24:658-68. https://doi.org/10.1007/s00268-009-0296-8

10. Geva T, Frand M, Benjamin P, Hegesh J. Cerebral embolization from an inferior vena cava thrombus in tetralogy of Fallot. Pediatric Cardiology 1990; 11(1):44-6. https://doi.org/10.1007/BF02239547
11. Higgins CB, Nukder DG. Tetralogy of Fallot in the adult. AmJ Cardiol 1972;29(6):837-46. https://doi.org/10.1016/0002-9149(72)90504-8

12. Gelbland H, Waldo AL, Kaiser GA, et al. Etiology of Right Bundle Branch Block in patients undergoing total correction of Tetralogy of Fallot. Circulation 1971; 44(6): 1022-33

13. Rosenbaum MB, Corrado G, Oliveri R, et al. Right bundle branch block with left anterior hemiblock surgically induced in tetralogy of Fallot: relation to the mechanism of electrocardiographic changes in endocardial cushion defects. Am J Cardiol 1970; 26(1):12-9.

https://doi.org/10.1016/0002-9149(70)90752-6

14. Chesler E, Beck W, Schrire V. Left anterior hemiblock and right branch block after surgical repair of tetralogy of Fallot. Am J Cardiol 1972; 84(1):45-52.

15. Lee W, Smith RS, Comstock $\mathrm{CH}$, et al.Tatralogy of Fallot: prenatal diagnosis and postnatal survival. Obstet Gynecol 1995; 86(4):583-88. https://doi.org/10.1016/0029-7844(95)00245-M

16. Bronhstein M, Zimmer E, Gerils L, et al. Early ultrasound diagnosis of fetal con genital heart defects in high risk and low risk pregnancies. Obstet Gynecol 1993;82(2):225-9.

17. Olley PM, Coceani F, Bodach E. E-type prostaglandins: a new emergency therapy for certain cyanotic congenital heart malformations. Circulation 1976;54(4):728-31.

https://doi.org/10.1161/01.CIR.53.4.728

18. Cumming G. Propranolol in Tetralogy of Fallot. Circulation 1970;(41):13-5. 
19. Garson A, Gillette PC, McNamara DG. Propanolol: The preferred palliation for tetralogy of Fallot. Am J Cardiol 1981;47(5):1098-104. https://doi.org/10.1016/0002-9149(81)90219-8

20. Gladman G, McCrindle BW, Williams WG, et al. The modified blalock-taussig shunt: clinical impact and morbidity in fallot $\mathrm{s}$ tetralogy in the current era.J Thorac Cardio vascular Surg 1997;114(1):25-50. https://doi.org/10.1016/S0022-5223(97)70113-2.

21. Al Habib H, Jacobs JP, Mavroudis C, et al. Contemporary Patterns of management of tetralogy of Fallot: Data from The Society of Thoracic Surgeons data- base. Ann Thorac Surg 2010;90(3):813-20. https://doi.org/10.1016/j.athoracsur.2010.03.110

22. Boshoff DE, Cools BLM, Heying R, et al. Off-label use of percutaneus pulmonary valved stents in the right ventricular outflow tract: Time to rewrite the label? Catheter Cardiovasc Interv 2013; 81(6):987-95. https://doi.org/10.1002/ccd.24594

23. Bertanou EG, Blackstone EH, Hezelrig JB, et al. Life expectancy without surgery in tetralogy of Fallot. Am J Cardiol 1978;42(3):458-66. https://doi.org/10.1016/0002-9149(78)90941-4
24. Murphy JG, Gersh BJ, Mair DD. Long term outcome in patients undergoing surgical repir of tetralogy of Fallot. N Engl. J Med 1993;(329):59399.

25. Nollert G, Fischlein T, Bouterwek S, et al. Longterm survival in patients with repair of tetralogy of Fallot: 36-year follow up of 490 survivors of the first after surgical repair. J Am Coll Cardiol 1997;30(5):1374-83. https://doi.org/10.1016/S0735-1097(97)00318-5

26. Bassareo PP, Mercuro G. QRS Complex enlargement as a predictor of Ventricular Arrhythmias in patients affected by surgically treated tetralogy of Fallot: a comprehensive literature review and historical overview. ISRN Cardiol 2013; (2013):1-8.

27. Dore A, Santagata P, Dubuc M, Mercier LA. Implantable cardioverter defibrilators in adults with congenital heart diseases: a single centre experience. Pacing Clin Electrophysiol 2004; 27:47-51 https://doi.org/10.1111/j.1540-8159.2004.00384.x 


\title{
Insuficijencija pulmonalnog zalistka kao komplikacija radikalnog hirurškog tretmana tetralogije Fallot
}

\author{
Milovan Stojanović ${ }^{1}$, Marina Deljanin-Ilić ${ }^{1,2}$, Aleksa Vuković ${ }^{1}$, Dejan Petrović1,2 \\ ${ }^{1}$ Institut za lečenje i rehabilitaciju Niška Banja, Niška Banja, Niš, Srbija \\ ${ }^{2}$ Univerzitet u Nišu, Medicinski fakultet, Niš, Srbija
}

\section{SAŽETAK}

Tetralogija Fallot predstavlja najčě̌ću cijanogenu urođenu srčanu manu. Dijagnoza se bazira na kliničkoj slici, EKG pregledu, ultrazvučnom pregledu srca, dodatnim imidžing metodama i invazivnom ispitivanju. Terapijski pristup bolesniku sa tetralogijom je kompleksan i zasniva se na konzvervativnim i radikalnim metodama. Bolesnici koji nisu podvrgnuti radikalnoj hirururškoj intervenciji imaju lošu prognozu, dok je prognoza operisanih neuporedivo bolja. Najčešća komplikacija hirurškog tretmana je insuficijencija plućnog zalistka koja obično zahteva reintervenciju, kao što je to bio slučaj kod našeg bolesnika.

Ključne reči: tetralogija Fallot, urođene srčane mane, insuficijencija pulmonalnog zalistka 